\title{
On Young Innovative Companies: why they matter and how (not) to policy support them*
}

\author{
Cédric Schneider \\ Copenhagen Business School, Denmark and K.U. Leuven, Belgium \\ Reinhilde Veugelers \\ K.U. Leuven, Belgium and European Commission (BEPA)
}

October 2008

\begin{abstract}
Recent policy initiatives in the EU aim at supporting so-called Young Innovative Companies (YICs). This paper provides empirical evidence from German CIS data on the innovative performances of this specific type of firms, supporting why they matter. We first characterize YICs in the sample of innovation active firms. We show that firms that combine newness, smallness and high R\&D intensity, are rare in the sample of innovative firms, but achieve significantly higher innovative sales than other innovative firms, especially innovative sales that are new to the market. Not surprisingly, YICs view financial constraints, both internal and external, as an important factor hampering their innovation activities, significantly more so than other innovation active firms. This access to finance problem is an often used motive for government intervention. In our German sample, subsidies schemes for innovation are general and not particularly targeted at YICs. We empirically assess the effectiveness of these public funding schemes. We find that these are not effective to increase the innovative sales of YICs, unlike the average innovative firm in our sample.
\end{abstract}

Keywords: Young Innovative Companies, innovative performance, subsidies JEL-Classification: G24, O31, 038

\footnotetext{
* We thank Georg Licht and the MIP team at the Centre for European Economic Research (ZEW, Mannheim, Germany) for granting us access to the data used in this paper. Financial support from the KULeuven (OT/07/011), the FWO (G.0523.08) and the PAI (P6/09) is gratefully acknowledged. Comments from V. Gaspar, D. Czarnitzki and B. Cassiman were very helpful. The paper reflects only the views of the authors and does not commit the European Commission.
} 


\section{Introduction}

The innovative performance of the US has attracted much attention trying to unravel the sources of its success. In the plethora of stories, the entrepreneurial capacity of the US is prominent (e.g. Christensen 1997). Small, entrepreneurial firms have been responsible for introducing major innovations in the US. With their radical innovations these companies reached fast growth and created the scene for new products, technologies and markets, on which other firms build further, enhancing these breakthroughs and adding to their overall usefulness. Baumol (2002) notes how fortunate the US has been to have this symbiosis of large and small firms.

The EU, in search of explanations for its persistent gap in innovative performance relative to US, often refers to its lack of young, dynamic enterprises. As compared to the US, the churning that characterizes the creative destruction process in a knowledge based economy is hindered in Europe, suggesting barriers to entry, exit, innovate and growth for new, small firms (see e.g. Bartelsmann et al., 2000). This hampers Europe's innovate and growth potential not only directly, but also indirectly. The EU is less likely to benefit from growth enhancing effects, the innovations from small and young firms may exert on the large incumbent firms.

To improve on their innovative and growth capacity, many EU countries have started to develop, particularly recently, a series of policy interventions to support young, innovative companies. The recently revised EU state aid rules for innovation support by its Members States allow for a more favorable treatment for Young, Innovative Companies (YICs). Several Member States have been introducing new measures to support the creation and growth of innovative companies, especially by improving their access to funding as well as providing support for innovation commercialization (BEPA, 2008).

Despite the high policy attention, surprisingly little empirical evidence exists to support the failing contribution of small entrepreneurial companies to innovative performance in Europe. This paper tries to provide some empirical evidence on the innovative performance of young, small innovative companies, using recent firm level 
evidence from Germany, i.e., the 2005 wave of the German Community Innovation Survey (CIS 4).

Also in Germany, newly founded innovative firms have attracted growing interest from politicians, looking at them as an answer to ongoing structural changes. Numerous studies have identified barriers for German start-ups to innovate and grow, related to Germany's tax system, its insolvency laws and its conservative banking system (Licht \& Nerlinger 1998). Although the growing policy attention has led to new government initiatives, most notably to improve access to finance, there is nevertheless a concern that these new initiatives are too ad hoc, complex, overlapping and not focused enough to reach the relevant targets and be effective (Licht \& Nerlinger 1998).

After identifying the target group of young, small, innovation-intensive companies among innovation active companies in Germany, we examine whether they are indeed more likely to be successful in introducing new innovations, particularly those radical innovations, which are new to the industry or market. Having checked whether these companies are more hampered than average in their innovative activities by barriers such as access to finance, we evaluate whether government support (in the form of subsidies) has helped to improve the innovative performance of YICs.

Our results for Germany support the specific character and importance of YICs. Even if they are small in numbers, YICs have a significantly higher innovative performance compared to other innovators, particularly for innovations that are new to the market. On the effectiveness of subsidies, our results are less positive. They suggest that the current subsidy allocation mechanisms, which are not targeted specifically to YICs, are not associated with better innovative performance of the subsidized YICs.

Before presenting these econometric results in section 4 , the paper starts with a discussion of the relevant issues and insights clarifying our hypotheses (Section 2), a presentation of the data and variables (Section 3) and some first summary statistics of the data (section 3). A concluding section summarizes and suggests further avenues for research. 


\section{Background}

\subsection{Defining Young, Innovative Companies (YICs)}

Since we are interested in innovative performance and companies that have the potential to develop important inventions with significant potential commercial applications, the focus will be on innovation active companies that are young and therefore typically of small size. The characteristics used to identify Young Innovative Companies (YICs) are therefore a combination of age, size and innovation profile.

A previously widely used concept is that of New Technology Based Firms (NTBFs), mostly defined as SMEs in high-tech sectors. ${ }^{1}$ Storey \& Thether (1998) provide an overview of NTBFs in Europe. NTBFs constitute only a small portion of firms in Europe. $^{2}$ Compared with start-ups in general, NTBFs exhibit faster average employment growth rates than other firms. But there is nevertheless an issue of EU NTBFs displaying lower post-entry growth rates as compared to US firms. This is consistent with the findings of a larger body of studies comparing the Schumpeterian process of creative destruction in the US and the EU, across all sectors and firms, innovative and non-innovative (see e.g. Bertelsmann et al., 2004). In the EU successful surviving entrants appear to grow more slowly than in the US. Europe particularly lacks extremely fast growing firms compared to the US (Veron and Philippon, 2008).

Another related concept, regularly used in the literature is that of "gazelles". These companies are solely defined on fast growth, and need not necessarily be small, young and innovation-active. In fact, many of the gazelles are not-innovation based. Hölzl

\footnotetext{
${ }^{1}$ The Arthur D. Little Group (1977) initially coined the concept, defining it as independently owned businesses established for not more than 25 years and based on the exploitation of an invention or technological innovation which implies substantial technological risks. However, in most subsequent empirical studies of NTBFs a broader definition is employed: namely those of SMEs in technology intensive sectors, thus dropping the concept of newness of the company and its technological activities. Many SMEs in technology intensive sectors could (and in fact are) merely adapting innovations already available on the market. This more common use of a broader definition of NTBFs reflects the available data, with company age and the nature of its innovative activities more difficult to collect, especially across countries.

${ }^{2}$ E.g. Licht \& Nerlinger (1998) report that perhaps only $1 \%$ to $5 \%$ of all new firms in Germany's manufacturing sector are based on advanced technologies.
} 
(2008) analyzing fast growing firms across EU countries, finds that although, they are more likely to be found in high-tech sectors and be more R\&D intensive than slowgrowing companies, many "gazelles", and particularly in countries further from the technology frontier, derive their fast growth from a broader set of competitive advantages, beyond innovation strictu sensu.

Since we are interested in innovation-active young and small companies, academic spin-offs, introducing drastic innovations based on new scientific developments, will be an important group of target companies. A large separate body of literature has developed on academic entrepreneurship (see Rothermael, 2008 for a recent survey). Our data do not allow identifying the (academic) origin of companies. Hence our analysis will include but not distinguish academic entrepreneurs.

\subsection{Why YICs matter for innovation}

If YICs justify attention, it will not be because they are large in numbers. In the population of firms, they represent only a very small number of companies even if expressed relatively to the selection of other small firms, other entrants or other innovators. As a consequence their direct contribution to an economy's employment or GDP cannot be substantial, even if they would display a superior performance. The attention to YICs is rooted in expectations on their effects on innovation, and particularly the more radical innovations that shape new markets. But are those expectations justified? Do YICs indeed contribute over-proportionally to innovative performance?

There is a large literature, dating back to Schumpeter 1942, discussing whether large or small firms matter more for innovation. While economies of scale and scope in the R\&D process and complementarities with other competences needed to commercialize, favor large firm innovations, arguments in favor for small firms are decreasing returns to scale in the production of innovation due to loss of managerial control and the bureaucratization of innovation activity. Much of the multivariate empirical analysis on the relationship between firm size and innovation, incorporating a wide set of firm and industry characteristics as control, has failed to find significant 
results for a positive (or negative) effect of firm size (see e.g. Kamien \& Schwartz (1982); Cohen \& Levin (1989)). Characteristics like market concentration, technological opportunities, the stage of the technology life cycle, all matter as intervening variables for the effect of firm size. Small firms are for instance more important in less concentrated industries (Acs and Audretsch, 1997) and in the early stages of the life cycle of an industry, particularly the small entrants (see e.g. Utterback, 1996).

Significant literature exists comparing the innovative behavior of new firms versus incumbents. The fear of cannibalization of existing profits restricts the incumbent's incentives to innovate (Reinganum, 1983), while the incentive to preempt entry pushes incumbent's innovations (Gilbert and Newbery, 1982). Whether entrants will spend more on innovation than incumbents and which indirect effect entry will have on incumbents' innovations depends inter alia on the likelihood of entry, the possibility for licensing (Gans and Stern, 2000), the strength of intellectual property protection (Anton and Yao, 1994), the stage in the industry life cycle (Klepper, 1996), the effectiveness of the market for ideas, the control over complementary assets, the association with venture capital, the likelihood of cooperation between entrants and incumbents (Gans, Hsu and Stern, 2002). Henderson and Clark (1990) and Henderson (1993) show how the nature of the innovation matters, i.e. whether the innovation is radical or incremental, incumbent competence enhancing or destroying. Empirical evidence on the photolitographic equipment industry confirms that for incremental innovations, incumbent firms spend significantly more on $R \& D$, while for radical innovation, entrants are more successful (Henderson 1993).

\subsection{Are YICs constrained in their innovative efforts?}

Overall the literature supports the importance of new, young and therefore often still small firms for innovations, even if they would be small in number. This holds directly for new, more radical innovations, and also indirectly by stirring follow-up innovations by incumbents. If this is the case, then factors that would inhibit these small, young companies to innovate can have a huge public impact. 
An important barrier to innovation is access to finance. There is a large literature demonstrating the substantial differences in this respect between small and large firms. Imperfections in capital markets usually affect small firms more than large firms, who can rely on more internal financing (Hall, 2005). With reputation and collateral being important to mitigate capital market imperfections, young firms are even more likely to be constrained than other small firms. More radical investment projects further exacerbate the imperfect, incomplete and asymmetric information problem. So YICs, combining the disadvantages of small scale, a short history, less retained earnings and more risky innovative projects, are even more likely to be financially constrained than other small or young or innovating firms.

A second barrier, arising from the difficulty of appropriating the benefits from innovation, also may play differently for YICs. They may find it more difficult to appropriate the direct returns from their innovations, often lacking the scale for a portfolio of appropriation strategies (Cassiman and Veugelers 2002) and complementary assets (eg Teece 1986, Gans \& Stern 2003). In addition, YICs may be unable to appropriate the surplus created by subsequent innovations that build on the knowledge introduced by the initial innovation. Particularly for initial innovations of the type that YICs are more likely to introduce, these follow-up innovations may be quite large. When large incumbents follow-up the YIC's innovations, they may not be fully compensating the pioneering YIC, when the market for technology disfavors small, young and risky projects (see Gans and Stern, 2003). Hence, as YICs are less able to capture the externalities that they generate, the larger would be the divergence between their social and private rate of return of their R\&D.

\subsection{Should governments support YICs and how?}

A typical next step in the argumentation is a need for policies to address the barriers to innovate for YICs. Particularly the access to finance barrier, being rooted in financial market failure, is a prime motive for policy intervention, which most often takes the form of providing financial incentives, such as subsidies or loans. However, when designing YIC specific policies it is not sufficient to have established the case of YIC specific market failures. With uncertainty, risk, changing 
environments, incomplete, imperfect or asymmetric information, ineffective policy responses are also more likely.

A large body of econometrical studies examines the impact of subsidies on private R\&D spending, testing for the crowding-out hypothesis. In a survey of this literature, David, Hall and Toole (2000), conclude that these studies, although plagued by methodological issues, on average provide support in favor of no crowding out. More recent studies have come up with better data and methodologies (e.g. Wallsten, 2000 for the US; Czarnitzki and Aerts, 2004 for Flanders; Almus and Czarnitzki, 2007 for Germany; Takalo et al., 2008 for Finland; Lach, 2002 for Israel; Gonzàlez et al., 2005 for Spain). Most of these studies confirm the positive results.

Focusing on the crowding-out effects, this line of research typically does not identify the effects of subsidies on the (innovative) performance of recipients. They also ignore the issue of whether a more targeted policy towards specific firms, like the YICs, would be more or less favorable to positive effects. In a very recent study, Colombo et al (2008), provide evidence on Italian data for different effects of funding depending on the stage of development of the recipient firm. They found that new technology based firms benefit more (in terms of firm growth) than mature ones from financial support, especially if public funds are allocated through a selective evaluation process.

\subsection{Our contribution}

Our analysis contributes to the literature by analyzing the relationship between YICs and innovative performance. To this end, we use micro-data from Germany, i.e. the 2005 wave of the German Community Innovation Survey (CIS 4). This rich data set allows us to:

(i) identify YICs for Germany on the characteristics of size, age and innovation profile

(ii) characterize whether YICs are more constrained by barriers for innovation and econometrically investigate whether YICs are more constrained by access to finance than other innovators 
(iii) econometrically investigate whether YICs are indeed more likely to be innovation performing, and particularly more likely to introduce radical innovations;

(iv) econometrically investigate the impact of government support on the innovative performance of YICs.

Overall, the results confirm our presumption that YICs achieve higher innovative performances than do other firms. This result is particularly strong for "radical" type of innovations. We also find that access to finance is the most important factor that hampers YICs' innovation activities. We therefore evaluate the effectiveness of R\&D public funding and find that while on average $R \& D$ subsidies increase the innovative performances of firms, this result does not hold for YICs.

\section{Data and methodology}

\subsection{Sample}

The data used stem from the German part of the Community Innovation Survey (CIS) conducted by Eurostat in European Union Member States in 2005 (CIS-IV). We restrict attention to West German firms only, avoiding a source of heterogeneity that is outside our issues of interest. The survey contains questions related to the innovation strategies of firms. In addition, the questionnaire contains information on respondent's motives for innovation, perceptions of innovation barriers and effectiveness of appropriation strategies. Lastly, the survey contains quantitative information on the firm, such as sales, age or employment. For the remainder of our analysis, we focus on innovation active firms, as most of our variables of interest are only available for these firms (1,715 observations). Although the dataset is rich in variables, its main restriction is the cross-section nature of the dataset, limiting the construction of control variables for innovative performance and excluding a thorough analysis of the subsequent sales and employment growth performance patterns of these companies.

\subsection{Hypotheses and Variables}


The aim of this paper is basically twofold: (i) to study the differential innovative performances of YICs and (ii) to evaluate the differential efficiency of R\&D subsidies in affecting the innovative performance of recipients. This section discusses the variables used in the analysis. A list of variables and their definitions can also be found in Appendix 1.

\subsubsection{Defining YICs}

Our variable characterizing YICs follows the recently revised European Commission's State Aid rules ${ }^{3,4}$ which allow a more favorable treatment of national governments to provide R\&D subsidies and tax incentives to YICs. The YIC dummy takes a value of 1 if an innovation active company is less than 6 years old, has less than 250 employees and spends at least $15 \%$ of its revenues on R\&D.

Having identified YICs along EU State Aid Rules, a summary statistics analysis reported in section 4.1 provides a first characterization of YICs. We also have a look at how YICs score differently on perceived barriers to innovation. Section 4.2. provides the econometric analysis on innovative performance and subsidy effectiveness. Throughout the econometric analysis, we check the robustness of our results using alternative thresholds for age, size and/or R\&D intensity to characterize a YIC.

\subsubsection{YICs and innovative performance}

The main hypothesis we want to examine is whether YICs have a higher innovative performance as compared to other innovation-active firms, particularly with respect to more radical innovations.

\footnotetext{
${ }^{3}$ Young Innovative Enterprises are defined in the EU State Aid Rules as small Enterprises, less than 6 years old, having being "certified' by external experts on the basis of a business plan, as capable of developing products or processes which are technologically new or substantially improved and which carry a risk of technological or commercial failure, or have R\&D intensity of at least $15 \%$ in the last three years or currently (for start-ups).

${ }^{4}$ Note that Germany did not adopt the YICs status yet in its subsidy programs, therefore our results will not be driven by this new policy measure.
} 
To analyze innovative performance, we use three alternative dependent variables. First, we use the percentage of sales generated by new or substantially improved products or services (SSnewimp). Second, we measure innovative performance using the share of sales with products new to the firm $(S S n e w F)$. Finally, we use the share of sales generated by products new to the market (SSnewM). These three measures of innovative performance capture different degrees of "radicalness" of a firm's innovative output. The first measure encompasses sales from all type of innovations, new as well as substantially improved innovations. The second measure excludes cumulative innovations made within a focal firm, hence excluding improved followup innovations, but could include innovations which were not new to the market, but new to the firm. The third measure only takes into account those innovations that are new to the market. The latter measure is our closest measure for more "drastic" innovations. The degree of "newness to the market" is however based on a subjective evaluation of the respondents and might still include innovations which, although new to the market, but perhaps are not the radical new original breakthrough innovations we are most interested in. The survey contains no information to further codify the radicalness of innovations new to the market.

When regressing our measures of innovative performance on the YICs dummy, we also include a set of control variables. Following the literature, we include the size of the focal firm, measured by the logarithm of employment. As discussed supra, larger firms may have higher market power or may enjoy economies of scale and scope, raising the profitability of an innovation strategy. On the other hand, smaller firms are associated with less bureaucracy and thus may be more innovation efficient. By using a logarithmic specification we already are allowing for a more favourable treatment of smaller sized firms. We also include the logarithm of firm age. Young firms are not infected by the incumbency barriers to innovation. They may however be more exposed to finance constraints. We also control for the input of $R \& D$ resources into the firm's innovative process, measured by the ratio of (intramural) R\&D expenditures to sales (R\&D intensity). In addition, we include the nature of the innovative strategy, i.e. how basic the R\&D process is. More basic R\&D increases the risk of the innovation process, but entails a higher probability of generating drastic innovations. We measure basicness as the importance (on a scale from 1 to 5) of information from public research institutes and universities relative to the importance 
of customers and suppliers as an information source (Cassiman and Veugelers, 2006). Finally, we control for industry specific characteristics by including 14 sector dummies that were constructed based on their NACE codes, a nomenclature of economic activities in the European Community.

The model is estimated by OLS and Tobit, in order to account for the large degree of left censoring (or corner solution outcome). The latter correction is particularly important for the SSnewM and SSnewF specification.

The specifications we estimate can be summarized as:

(i) OLS: $\Pi_{i}=\alpha+\beta_{1} Y_{I C s_{i}}+\beta_{2} X_{i}+u_{i}$

(ii) Tobit: $\Pi_{i}=\max \left(0 ; \gamma+\delta_{1} Y I C s_{i}+\delta_{2} X_{i}+\varepsilon_{i}\right)$

Where $\Pi_{i}$ corresponds to our alternative measures of innovation performance and $X_{i}$ is a vector of controls containing age, size, $R \& D$ intensity, basicness and the sector dummies. The results are reported in section 4.2 .

\subsubsection{Subsidies, YICs, innovative performance}

Providing an overview of the initiatives that exist in Germany to subsidize innovative companies is not easy, as the responsibility for subsidy programs is distributed among several federal ministries, regional ministries (Länder) and autonomous organizations (see Licht and Nerlinger, 1998). ${ }^{5}$ Total public expenditures on R\&D in Germany originating from the federal level and the regional governments (Länder) are almost equally important. EU subsidies are less important (Licht and Nerlinger, 1998). Although SMEs are favored targets, most of the programs at the time of the survey do not seem to be specifically targeted at YICs. Direct public support from the federal level is more focused on specific areas of technology and specific regions ${ }^{6}$ rather than on specific types of firms (Licht and Nerlinger, 1998). ${ }^{7}$ Also at EU level there were, at

\footnotetext{
${ }^{5}$ In fact, the huge number and complexity of programs offered by the several agencies and ministries, is often quoted as a factor limiting the effectiveness of these programs. A lot of particularly small and young firms are not applying for programs that are available for them, for lack of resources and information. This is why a simplification of the support schemes has taken place in more recent years.

${ }^{6}$ At the time of the survey, a substantial part of federal government R\&D expenditures was dedicated to the ongoing transformational process in the east of Germany after the reunification in 1989. This is one of the reasons we focus on analysis on West German companies only.

${ }^{7}$ The Federal Government in Germany has more recently implemented a tripartite structure to improve financing for technology-based start-ups, especially concerning access to venture capital (VC). The ERP Innovation program, a loan program for R\&D and innovation financing in SMEs, is redesigned in
} 
the time of the sample, no specific subsidy schemes or favorable treatments in existing schemes for YICs.

In order to asses the effectiveness of public funding, we use in the innovative performance regression a dummy variable indicating whether a focal firm was subsidized by the German federal government, by the regional government in which they are located, or by the European Union (Subsidized). ${ }^{8}$ We include the subsidy dummy in the innovative performance analysis as well as an interaction between the YICs and subsidy dummy. This allows us to evaluate the effectiveness of receiving subsidies for all firms, but also differentially for YICs.

It is important to mention that we are restricted to a cross-sectional approach, regressing contemporaneous subsidies on innovative performance. However, the receipt of public subsidies is highly persistent over time. For example, Aerts (2008) for Flanders and Hussinger (2008) for Germany show that past subsidies are strongly related to receiving current public funding. Therefore, we argue that current subsidies are a good approximation of a firm's R\&D funding history.

Regressing any measure of research output on the receipt of a R\&D subsidy is not unproblematic. The selection problem that arises in attempting to assess the impact of a public program is well known in the economic literature (Heckman et al., 1998; Klette et al., 2000; David et al., 2000 or Jaffe, 2002). Variables that are unobservable by the econometrician might be correlated with the receipt of a public subsidy. These variables could be the budgets submitted to the agency, the agency's personal knowledge of the applicants or the quality of the research projects proposed (Jaffe, 2002). Therefore, the subsidy dummy is unlikely to be exogenous, which is why we use an instrumental variable (IV) approach.

The typical instruments used to tackle this issue are the yearly or industry-specific available budgets (Lichtenberg, 1988; Wallsten, 2000). Since we do not have

order to better address current market failures in loan financing of innovation. None of these programs are specifically dedicated to YICs.

${ }^{8}$ We have no information on the amount of subsidies received, nor any other public support. Typically, sample firms that receive subsidies from one funding agency are also likely to receive R\&D grants from other agencies. This precludes analyzing the effectiveness of subsidies by funding agency in our sample. 
information about the funding agencies' budgets, we use two alternative (but closely related) instruments. We hypothesize that the probability of receiving a R\&D subsidy depends on the preferences of public policy agents, as expressed through their specific public policies in place. We characterize these public policies along their regional and technological dimensions. The first instrument we use is the share of subsidized firms in the region where the focal firm is established. We hypothesize that a region with a high share of subsidized firms reflects a targeted policy objective from the government or the regional authorities, for example an affirmative action type of policy that leads the authorities to subsidize firms in less developed regions. In the same vein, we also use the share of subsidized firms per industry (at the NACE 2-digit level), the presumption being that specific industrial policies will lead the funding authorities to favour one or the other sector of the economy. Both assumptions, namely a regional and technology specific preference in R\&D subsidy schemes, seem to hold in the case of Germany (Licht and Nerlinger, 1998).

If the subsidy dummy is correlated with the unobservables, then the interaction term between the subsidy and YICs dummies is also expected to be endogenous. Therefore, we follow Wooldridge (2001) and use the interactions between the instruments presented above and the YICs dummy as a source of exogenous variation in the first stage equation.

In the linear case, we use standard two-stage least squares (2SLS) methods. In the Tobit case we use Newey's two-step approach. We estimate the first stage equations with linear probability models, since this will yield consistent estimates in the equation of interest (if the instruments are valid), whether or not the first stage equation is linear (Angrist, 2001; Wooldridge, 2002).

The results on the impact of subsidies on innovative performance are reported in section 4.3. In order to motivate our focus on subsidies, we also provide some econometric evidence, reported in the Appendix, on whether YICs are indeed more likely to be financially constrained. As measure for financial constraint, we use the respondent's perception of lack of financing (both internal as well as external) as barrier to innovation. Since these variables are not measuring the actual financial constraints, but only the awareness of the respondent, we do not use this information 
further in the subsidy-innovative performance analysis. As also other studies have shown using similar data (Mohnen et al. 2008; Tivari et al., 2007; Savignac, 2008), it is often the companies most active in innovation and who have been active on the financial markets that are more "aware" of the constraints, but are not necessarily more constrained. ${ }^{9}$ The sample does not provide objective financial information on actual constraints.

\section{Results}

\subsection{Some descriptive analysis}

\subsubsection{Characterizing YICs}

Out of our sample of 1342 innovation-active companies, only 51 companies qualify for YIC status, using our EU State Aid definition. This confirms the "rareness" of YICs, representing only $3.8 \%$ of all innovation-active companies in West-Germany in 2005. Even within the group of small innovators or young innovators, YICs are rare (resp $4.3 \%$ and $24 \%$ ).

Table 1: summary statistics

\begin{tabular}{|c|c|c|c|}
\hline \multirow[b]{2}{*}{ Variables } & \multicolumn{3}{|c|}{$\begin{array}{l}\text { YICs } \\
(\mathrm{N}=51)\end{array}$} \\
\hline & $\mathrm{N}$ & Mean & S.D. \\
\hline Size & 51 & 19.686 & 33.969 \\
\hline Age & 51 & 4.196 & 1.341 \\
\hline R\&D intensity & 51 & 0.638 & 1.173 \\
\hline Basicness & 49 & 0.807 & 0.488 \\
\hline Part of a group & 50 & $40.00 \%$ & 0.495 \\
\hline
\end{tabular}

\begin{tabular}{l|c|c|c|cc|cc|cc|c|c|c|} 
& \multicolumn{3}{|c|}{$\begin{array}{c}\text { Other innovators } \\
(\mathrm{N}=1342)\end{array}$} & \multicolumn{3}{c|}{$\begin{array}{c}\text { Other young Innovators } \\
(<6 \text { yrs old })(\mathrm{N}=213)\end{array}$} & \multicolumn{2}{c|}{$\begin{array}{c}\text { Other small innovators } \\
(<250 \text { empl)(N=1187) }\end{array}$} & $\begin{array}{c}\text { Other } R \& D \text { intensive innovators } \\
(\mathrm{R} \& \mathrm{D} \text { intensity }>15 \%)(\mathrm{N}=501)\end{array}$ \\
\hline \hline Variables & $\mathrm{N}$ & mean & S.D. & $\mathrm{N}$ & mean & S.D. & $\mathrm{N}$ & mean & S.D. & $\mathrm{N}$ & Mean & S.D. \\
\hline \hline \multirow{2}{*}{ Size } & 1342 & 1274.723 & 9878.847 & 213 & 241.770 & 672.477 & 1187 & 61.568 & 64.445 & 500 & 1936.292 & 20561.220 \\
Age & 1342 & 36.688 & 37.812 & 213 & 4.075 & 1.597 & 1182 & 30.888 & 33.258 & 497 & 30.867 & 33.778 \\
R\&D intensity & 1342 & 0.0880 & 0.858 & 181 & 0.216 & 0.674 & 970 & 0.136 & 1.049 & 187 & 0.568 & 2.346 \\
Basicness & 1285 & 0.548 & 0.423 & 197 & 0.572 & 0.388 & 1081 & 0.517 & 0.432 & 422 & 0.612 & 0.517 \\
Part of a group & 1328 & $67.02 \%$ & 0.470 & 209 & 0.598 & 0.491 & 1173 & 0.541 & 0.499 & 491 & 0.578
\end{tabular}

\footnotetext{
${ }^{9}$ Also in our sample, when we include financial constraints in the performance regression, the perceived financial constraints have a positive correlation with innovation performance. We lack relevant instruments to correct this bias.
} 
A "typical" YIC has a micro size, with about 20 employees. This is considerably smaller than other innovating SMEs, as well as young innovators and especially other R\&D intensive innovators. Also on R\&D intensity and basicness of its R\&D profile, a "typical" YIC scores much higher than any of these reference categories. These statistics confirm that it is a combination of age, size and R\&D profile that composes the particularity of YICs. YICs are not the same as innovative SMEs, young innovators or R\&D intensive innovators.

Although YICs are much less likely to be part of a group as compared to other firms, 4 out of 10 YICs are nevertheless part of a group. It is however not possible to identify in the dataset the nature and importance of this group relationship, how it affects the independence of the company, which is why we ignore this dimension in the analysis. ${ }^{10}$

Table 2 disaggregates all firms in our sample by sectoral classification and shows that YICs are concentrated in a few sectors only. More specifically, YICs are overrepresented in knowledge-intensive, technological sectors, specifically services (ICT and R\&D engineering) while they are absent in more traditional manufacturing industries.

Table 2: Industry classification

\begin{tabular}{cl|cc|cc} 
& & \multicolumn{2}{|c|}{ YICs } & \multicolumn{2}{c}{ Other Innovators } \\
Sector & & Frequency & $\%$ & Frequency & $\%$ \\
\hline \hline 1 & food and Tobacco & 0 & $0.00 \%$ & 41 & $3.06 \%$ \\
2 & Textiles and leather & 1 & $1.96 \%$ & 38 & $2.83 \%$ \\
3 & Wood, paper and publishing & 4 & $7.84 \%$ & 101 & $7.53 \%$ \\
4 & Chemicals and petroleum & 6 & $11.76 \%$ & 152 & $11.33 \%$ \\
5 & glass, ceramics and furnitures & 0 & $0.00 \%$ & 38 & $2.83 \%$ \\
6 & Metal & 0 & $0.00 \%$ & 144 & $10.74 \%$ \\
7 & Machinery and equipment & 0 & $0.00 \%$ & 136 & $10.14 \%$ \\
8 & electrical machinery, medical and optical instruments & 6 & $11.76 \%$ & 197 & $14.69 \%$ \\
9 & Motor vehicles & 1 & $1.96 \%$ & 52 & $3.88 \%$ \\
10 & sales of motor vehicles, wholesale and retail trade & 0 & $0.00 \%$ & 66 & $4.92 \%$ \\
11 & Transportation and communication & 1 & $1.96 \%$ & 76 & $5.67 \%$ \\
12 & ICT & 12 & $23.53 \%$ & 85 & $6.34 \%$ \\
13 & Research, experimental development and engineering & 17 & $33.33 \%$ & 85 & $6.34 \%$ \\
14 & Consulting & 3 & $5.88 \%$ & 130 & $9.69 \%$
\end{tabular}

\footnotetext{
${ }^{10}$ We ran regressions that include a variable indicating whether or not a firm belongs to a group. The coefficient on this variable was insignificant and the other coefficients remained unchanged.
} 


\subsubsection{YICs and barriers to innovation}

Table 3 presents the results on whether YICs perceive differently obstacles to innovation. Respondents were asked to give a score to each (potential) hampering factor on a scale going from zero (not relevant) to three (high). The first column indicates the share of firms that considered this factor to be relevant (i.e. firms that scored one or more), while the second column reports the average score.

\section{Table 3: Obstacles to innovation}

\begin{tabular}{l|c|c|cc|c} 
& \multicolumn{2}{|c|}{ YICs } & Other Innovators & \\
\hline & & mean & & Mean & mean \\
diff. with \\
Barriers to innovation & $\%$ & score & $\%$ & score & YICs \\
\hline External financial constraints & $95.65 \%$ & 2.283 & $75.75 \%$ & 1.234 & $-1.049 * * *$ \\
Internal financial constraints & $93.30 \%$ & 2.457 & $66.42 \%$ & 1.382 & $-1.074 * * *$ \\
Innovation costs too high & $93.33 \%$ & 2.356 & $87.71 \%$ & 1.862 & $-0.493 * * *$ \\
Uncertain demand for innovative products & $89.13 \%$ & 1.435 & $74.60 \%$ & 1.241 & -0.193 \\
Regulations & $71.74 \%$ & 1.196 & $64.70 \%$ & 1.122 & -0.073 \\
Lack of qualified personnel & $71.74 \%$ & 1.087 & $72.56 \%$ & 1.163 & 0.076 \\
Lack of information on technology & $69.57 \%$ & 0.935 & $63.20 \%$ & 0.82 & -0.115 \\
Lack of information on markets & $69.57 \%$ & 1.087 & $67.56 \%$ & 0.961 & -0.125 \\
Difficulty of finding cooperation partners & $67.39 \%$ & 1.109 & $53.90 \%$ & 0.785 & $-0.323 * *$ \\
Market dominated by established firms & $65.22 \%$ & 1.152 & $62.14 \%$ & 1.018 & -0.134 \\
No demand for innovation & $54.55 \%$ & 0.818 & $51.74 \%$ & 0.803 & -0.015 \\
Resistance to change & $52.17 \%$ & 0.630 & $60.08 \%$ & 0.811 & 0.180
\end{tabular}

As expected, YICs face, on average, higher obstacles to innovation than other innovating firms. When comparing across barriers, the results confirm the presumption that financial constraints are the most important barriers to innovation for YICs, both internal and external financial constraints. Although this ranking holds for other innovating firms too, the YIC-differential is largest on both financial constraints and strongly statistically significant.

As concerns other barriers to innovation, YICs are more impeded by uncertainty of demand for their innovations. This is consistent with a higher risk/radicalness profile of their innovations as compared to other innovators. Despite this high risk profile, YICs seem to be less impeded by "resistance to change". However, none of these differences are statistically significant. Regulations score higher as barriers for YICs 
than for other innovators, but again the difference is not significant. Also, lack of information and lack of qualified personnel are important barriers for YICs, but to a very similar extent as other innovators. The "market dominated by established firms" barrier scores somewhat stronger for YICs as compared to other innovators, but the difference is again not significant. Only on difficulty of finding cooperative partners, there is a significantly higher effect for YICs.

For none of the barriers, except for internal and external financial constraints, a YICs differential effect survives an econometric analysis, correcting for other firm and industry characteristics. Appendix 2 provides the results from an ordered probit model to explain the importance of access to finance (internal and external) as barrier to innovation. The results confirm that small innovators are more likely to be financially constrained (both internally and externally), and so are innovators that have a more basic innovative profile. But on top of these effects, YICs are significantly more likely to be financially constrained (both internal and external). These results therefore support the case for public policy attention targeting access to finance for YICs.

\subsubsection{YICs and subsidies}

Table 4 provides some further descriptive statistics on YICs and subsidies. The mean value of this variable reveals that YICs are heavily subsidized, since more than $40 \%$ of them received subsidies. This compares to only $14 \%$ for all innovators, $11 \%$ for small innovators, $17 \%$ for young innovators and only $20 \%$ for R\&D intensive innovators.

Table 4: YICs and subsidies

\begin{tabular}{l|ccc|} 
& \multicolumn{3}{|c}{ YICs } \\
Variable & $\mathrm{N}$ & mean & S.D. \\
\hline Received subsidies & 31 & 0.419 & 0.502
\end{tabular}

\begin{tabular}{l|cc|cc|cc|cc} 
& \multicolumn{2}{|c|}{$\begin{array}{c}\text { Other } \\
\text { innovators }\end{array}$} & \multicolumn{2}{|c|}{ Other young innovators } & \multicolumn{2}{|c|}{ Other small innovators } & \multicolumn{2}{|c}{ Other R\&D intensive innovators } \\
Variable & mean & S.D. & mean & S.D. & mean & S.D. & mean & S.D. \\
\hline Received subsidies & 0.139 & 0.346 & 0.171 & 0.378 & 0.113 & 0.316 & 0.218 & 0.414
\end{tabular}


The most frequently observed funding agency is the German Federal Government (44\%), followed by regional authorities (28\%) and the European Union (24\%). The distribution of subsidies received by YICs across funding agencies is exactly the same as in the overall sample of innovative firms. Typically, firms that receive subsidies from a given funding agency also receive $R \& D$ grants from at least one of the other agencies: $87 \%$ of firms that received a subsidy from the Federal Government also got a subsidy from another authority, $85 \%$ for the regional authorities, $86 \%$ for the EU and $77 \%$ for other agencies. This high level of co-occurrence of subsidies from different granting agencies, makes it difficult to disentangle the funding agency in the analysis on the effectiveness of subsidies.

\subsubsection{YICs and innovative performance}

Table 5 provides some summary statistics on the innovative performance of YICs. These first results suggest that YICs on average have substantially higher sales from new or substantially improved products, as compared to other innovators (SSnewimp). The differential amounts to 2.4 times. This differential is smaller when comparing with other young innovators and other R\&D intensive innovators, which are typically older and larger, but it is nevertheless still substantial and statistically significant. For our measure of more radical innovations, share of sales with market novelties $(S S n e w M)$, the performance differential for YICs over other innovators is even more impressive, with YICs scoring 5 times higher on average than other innovators on average, 2.5 larger than other $R \& D$ intensive innovators or other young innovators. Also for our measure share of sales with products new to the firm (SSnewF), the YIC differential is higher (again 5 times larger). Although standard deviations are substantial, the mean difference remains statistically significant. These first summary statistics are supportive of the notion that YICs superior innovative performance comes out most strongly for innovations that are not improvements to existing innovations, even if these improvements are important.

Table 5: YICs and Innovative Performance

\begin{tabular}{l|lll} 
& \multicolumn{3}{|c}{ YICs } \\
Variables & $\mathrm{N}$ & mean & S.D. \\
\hline \hline
\end{tabular}




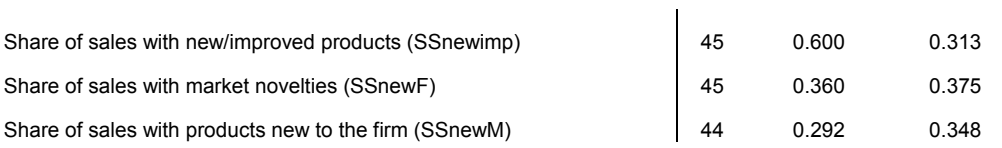

\begin{tabular}{|c|c|c|c|c|c|c|c|c|c|c|c|c|}
\hline Variables & \multicolumn{3}{|c|}{ Other innovators } & \multicolumn{3}{|c|}{ Other young innovators } & \multicolumn{3}{|c|}{ Other small innovators } & \multicolumn{3}{|c|}{ Other R\&D intensive firms } \\
\hline Share of sales with new/improved products & 0.261 & 0.244 & *** & 0.377 & 0.326 & *** & 0.291 & 0.272 & *** & $35.82 \%$ & 0.304 & *** \\
\hline Share of sales with market novelties & 0.072 & 0.144 & *** & 0.145 & 0.264 & 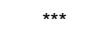 & 0.091 & 0.190 & *** & $12.95 \%$ & 0.243 & $\star \star \star *$ \\
\hline Share of sales with products new to the firm & 0.058 & 0.112 & *** & 0.140 & 0.259 & $\star \star \star$ & 0.075 & 0.155 & $* \star *$ & $9.38 \%$ & 0.192 & *** \\
\hline
\end{tabular}

On growth of sales or employment, measured over the period 2002-2004, YICs score significantly higher: their average sales growth is $61 \%$, compared to "only" $24 \%$ for other innovators. Similarly for employment growth, YICs report an average 24\% versus $6 \%$ for other innovators. This confirms that YICs extend their superior innovative performance into a higher performance on sales and employment growth as well, easily qualifying as "gazelles".

\subsection{Econometric results}

\subsubsection{Baseline results: the innovative performances of YICs}

In order to evaluate the innovative performances of YICs relative to other types of firms, we first regress the YICs dummy and the control variables on our measures of innovative performance. These first set of results are presented in Table 4. The models are estimated by OLS and Tobit, in order to account for the large degree of left censoring in some of the dependent variables. This correction is particularly important for the results on innovations excluding serious improvements, i.e. the share of sales with market novelties and share of sales with products new to the firm, as the number of left censored observations is considerable for those variables.

The results reveal that YICs achieve, on average, a higher innovation performance than other innovators. This result holds for all type of innovation measures but the effect is stronger for the measure of sales with market novelties $(S S n e w M)$ and weaker for sales with products new to the firm (SSnewF), suggesting that YICs are most differentially successful when it comes to introducing innovations new to the market, which confirms our hypothesis. 
Table 4: Estimation results for YICs and innovative performance (1)

\begin{tabular}{|c|c|c|c|c|c|c|c|c|c|c|c|c|c|c|c|c|c|c|}
\hline & \multicolumn{6}{|c|}{$\begin{array}{l}\text { Share of sales with new/improved products } \\
\text { SSnewimp }\end{array}$} & \multicolumn{6}{|c|}{$\begin{array}{l}\text { Share of sales with products new to the firm } \\
\text { SSnewF }\end{array}$} & \multicolumn{6}{|c|}{$\begin{array}{l}\text { Share of sales with market novelties } \\
\text { SSnewM }\end{array}$} \\
\hline & \multicolumn{3}{|c|}{ OLS } & \multicolumn{3}{|c|}{ Tobit } & \multicolumn{3}{|c|}{ OLS } & \multicolumn{3}{|c|}{ Tobit } & \multicolumn{3}{|c|}{ OLS } & \multicolumn{3}{|c|}{ Tobit } \\
\hline $\log ($ age $)$ & -0.009 & ** & 0.004 & -0.008 & * & 0.004 & -0.007 & * & 0.004 & -0.012 & * & 0.007 & -0.009 & * & 0.005 & -0.021 & ** & 0.009 \\
\hline log(employment) & -0.016 & * & 0.008 & -0.016 & * & 0.008 & -0.006 & $* \star *$ & 0.002 & -0.002 & & 0.004 & -0.004 & & 0.003 & 0.008 & & 0.005 \\
\hline Basic $R \& D$ reliance & -0.006 & & 0.016 & -0.009 & & 0.018 & -0.005 & & 0.009 & -0.004 & & 0.015 & -0.011 & & 0.011 & -0.019 & & 0.020 \\
\hline YICs & 0.205 & *** & 0.054 & 0.209 & *** & 0.043 & 0.136 & $* \star \star$ & 0.023 & 0.177 & $* * *$ & 0.035 & 0.202 & *** & 0.028 & 0.268 & $* \star *$ & 0.045 \\
\hline Industry dummies & \multicolumn{3}{|c|}{ Included } & \multicolumn{3}{|c|}{ Included } & \multicolumn{3}{|c|}{ Included } & \multicolumn{3}{|c|}{ Included } & \multicolumn{3}{|c|}{ Included } & \multicolumn{3}{|c|}{ Included } \\
\hline Constant & 0.286 & *** & 0.038 & 0.274 & *** & 0.036 & 0.093 & *** & 0.019 & -0.006 & & 0.032 & 0.075 & $\star \star \star *$ & 0.023 & -0.098 & ** & 0.042 \\
\hline
\end{tabular}

Regarding the control variables, the data confirm that R\&D intensive, young and small firms are more successful in introducing innovative products. ${ }^{11}$ The basicness of a firm's R\&D seems to have no significant effect on innovative performance. ${ }^{12}$ Important to note is that, even when correcting for firm size, age, R\&D intensity and the basicness profile of the firm's innovation strategy, the significant positive effect for YICs prevails. This implies that YICs display a superior innovative performance on top of the fact that they are small, young, R\&D intensive and have a more basic R\&D profile. It reflects the additional affect of combining youth, a small size and a highly R\&D intensive profile. ${ }^{13,14}$

\footnotetext{
${ }^{11}$ Similar results are obtained (i.e. a significantly positive coefficient for YICs) when including categorical dummies for firm size, age and R\&D intensities, rather than $(\log )$ linear version of these variables.

${ }^{12}$ Ignoring the variable in the analysis does not affect the results on the other coefficients.

${ }^{13}$ Note that our YIC dummy is not the same as including an interaction term of size, age and R\&D intensity. Such an interaction term would imply a combined effect of the three variables similar across the whole distribution. Our YIC dummy captures only a combination from size, age and R\&D intensity, in the interval of young, small and highly R\&D intensive firms, which is where the strongest arguments are for expecting a combined effect.

${ }^{14}$ In order to check whether the YIC dummy is merely picking up some extra non-linearity in the size, age or R\&D intensity dimension which we have not sufficiently controlled for, we also included in the regression on top of the existing variables, 3 extra dummies, one for young firms $(<=6)$, one for small firms $(<=250)$ and one for high R\&D intensity $(>15 \%)$. The YICs coefficient remains highly significant and at very similar level for the SSnewF and SSnew $M$ specifications. In the SSnewimp specification, the YIC coefficient remains significant but looses half of its value. The age and size dummies are never significant, indicating that beyond the logarithmic specification for age and size, there are no extra non-linearities in size and age to account for. For R\&D intensity, the dummy turns out significantly positive in the SSnewimp and the SSnewM, but not in the SSnewF. Also, other nonlinear specifications for RDI hint at a convex relationship, with companies at the very high end of the R\&D intensity distribution, being more innovative performing. Nevertheless, despite this non-linearity in RDI, YICs who combine high RDI with a young age, significantly and substantially outperform these counterparts.
} 


\subsubsection{Sensitivity of performance effects with respect to YIC definition}

Table 5 summarizes the results from a robustness analysis on the identification of the YICs target group. Relaxing unilaterally the size criterion does not yield many extra observations, as long as the age constraint is maintained. When we extend the size criterion to 500 employees, we gain only 3 extra observations for YICs. Dropping size altogether, i.e. targeting young innovation-intensive firms, results in 4 extra YIC cases. None of the reported results change with these limited number of extra cases, and are therefore not reported. The most sensitive changes involve the age and RDI criterion. Expanding the age criterion to 15 years (scenario 2), would yield 48 extra YIC cases. ${ }^{15}$ Dropping the age constraint altogether (scenario 3), i.e. targeting small, innovative-intensive companies, irrespective of their age, would leave 139 positive cases. While the superior performance effects are only marginally affected for new or improved innovations (SSnewimp), the effects excluding improvements are more seriously affected, especially on innovations new to the firm (SSnewF). Reducing the $\boldsymbol{R} \boldsymbol{\&} \boldsymbol{D}$ intensity criterion to $8 \%$, which is the sample average, would yield 21 extra YIC cases (scenario 4). The results on SSnewimp and SSnewF are only marginally affected, but the superior YIC effect for innovative sales new to the market (SSnewM) drops substantially, albeit remaining significant. Dropping the RDI criterion altogether, i.e. targeting, young and small innovators, would result in 139 positive cases (scenario 5). In this case, the YIC effect is substantially reduced, most notably on the innovative sales new to the market dimension (SSnewM). Relaxing simultaneously the age, size and RDI criteria to more generous levels (scenario 6: resp $<15,<500$ and $>8 \%$ ) would give 166 YICs, $12 \%$ of innovative companies in the sample. The superior YICs effect is again only marginally affected for new or improved innovations (SSnewimp), but more seriously affected for innovations new to the market $(S S n e w M)$ and new to the firm $(S S n e w F)$. Nevertheless, in all cases a significant superior innovative performance effect remains.

\section{Table 5: Results for the YICs coefficient in innovative performance using alternative YIC scenarios \\ Tobit Results}

\begin{tabular}{|l|l|l|l|l|l|l|l|}
\hline & Age & Size & RDI & YIC & YICs in & YICs in & YICs in \\
\hline
\end{tabular}

\footnotetext{
${ }^{15}$ An age criterion of 15 is currently being advocated by the Biotech sector. Interestingly in our sample, the extra observations from relaxing the age constraint are not found in bio-tech, but mostly in ICT and instruments.
} 


\begin{tabular}{|c|c|c|c|c|c|c|c|}
\hline & Criterion & Criterion & Criterion & observations & SSnewimp & SSnewF & SSnewM \\
\hline 1 & $<6$ & $<250$ & $>15 \%$ & 51 & $\begin{array}{c}0.209 * * * \\
(0.043)\end{array}$ & $\begin{array}{c}0.177^{* * * *} \\
(0.035)\end{array}$ & $\begin{array}{c}0.268 * * * \\
(0.045)\end{array}$ \\
\hline 2 & $<15$ & $<250$ & $>15 \%$ & 99 & $\begin{array}{c}0.221^{* * *} \\
(0.033)\end{array}$ & $\begin{array}{c}0.112 * * * \\
(0.027)\end{array}$ & $\begin{array}{c}0.263^{* * * *} \\
(0.034) \\
\end{array}$ \\
\hline 3 & All & $<250$ & $>15 \%$ & 139 & $\begin{array}{c}0.189 * * * \\
(0.026)\end{array}$ & $\begin{array}{c}0.037 * * * \\
(0.022) \\
\end{array}$ & $\begin{array}{c}0.166^{* * * *} \\
(0.029) \\
\end{array}$ \\
\hline 4 & $<6$ & $<250$ & $>8 \%$ & 72 & $\begin{array}{c}0.189 * * * \\
(0.037)\end{array}$ & $\begin{array}{c}0.173 * * * \\
(0.030)\end{array}$ & $\begin{array}{c}0.183^{* * * *} \\
(0.041) \\
\end{array}$ \\
\hline 5 & $<6$ & $<250$ & All & 139 & $\begin{array}{l}0.071^{* *} \\
(0.029) \\
\end{array}$ & $\begin{array}{c}0.092 * * * \\
(0.025)\end{array}$ & $\begin{array}{l}0.079^{* *} \\
(0.033) \\
\end{array}$ \\
\hline 6 & $<15$ & $<500$ & $>8 \%$ & 166 & $\begin{array}{c}0.170^{* * *} \\
(0.027)\end{array}$ & $\begin{array}{c}0.054^{* *} \\
(0.024)\end{array}$ & $\begin{array}{c}0.189^{* * * *} \\
(0.030)\end{array}$ \\
\hline
\end{tabular}

Overall, these sensitivity results suggest that the superior YIC innovative performance effect is robust, at least for not too drastic and unidimensional changes to the criteria and particularly for innovative performance that includes improvements (SSnewimp). However for innovations new to the market and new to the firm, the superior performance of the target groups, although still significant, becomes less impressive, particularly when affecting the age and R\&D intensity criterion substantially or in combination.

Finally, we also checked the sensitivity of our results when using a definition reflecting New Technology Based Firms (NTBFs). 498 companies (or almost one third of all sample innovative firms) classify as SMEs in high-tech sectors, with hightech sectors identified as our sectors 4 (chemicals), 8 (electrical machinery \& instruments), 12 (ICT services) and 13 (R\&D services). Interestingly, the NTBF dummy never shows up significantly in any innovative performance regression, once correcting for size and sectors.

\subsubsection{YICs and subsidies}

In this section we examine the effectiveness of public support for innovative performance, and particularly public support for YICs, in the form of subsidies. The results reported in section 4.1, documenting the significantly larger internal and external financial constraints perceived by YICs, support the case for public policy 
attention targeting access to finance for YICs, particularly as this barrier is rooted on market failure. This however does not imply that subsidy policies will be successful, as government failure may arise.

In order to assess the effectiveness of government subsidies on innovative performance of recipients, we introduce in the innovative performance regression, the subsidy dummy, reflecting whether the innovator has received subsidies or not. We also include an interaction variable taking a value of 1 if it concerns a subsidized YIC. As there are many missing observations for the subsidy variable, this part of the analysis is performed with a significantly lower sample size. The results using OLS and Tobit are reported in Table 6, while the IV results are reported in Table 7.

Overall, the signs and magnitudes of the coefficient for the controls do not change significantly when the additional subsidy variables are introduced in the OLS and Tobit analysis (Table 6). The overall effect of YICs remains strongly positive and significant in all three specifications.

Subsidies have a positive effect on innovation performance, an effect which is significant for the SSnewimp and SSnewM specification. Interestingly, there is no significant additional effect for subsidized YICs. Subsidized YICs perform as well as other YICs and the effect of subsidies on innovative performance is as high for YICs as it is for other subsidized companies.

Table 6: Estimation results for YICs, subsidies and innovative performance

(1) OLS \& Tobit

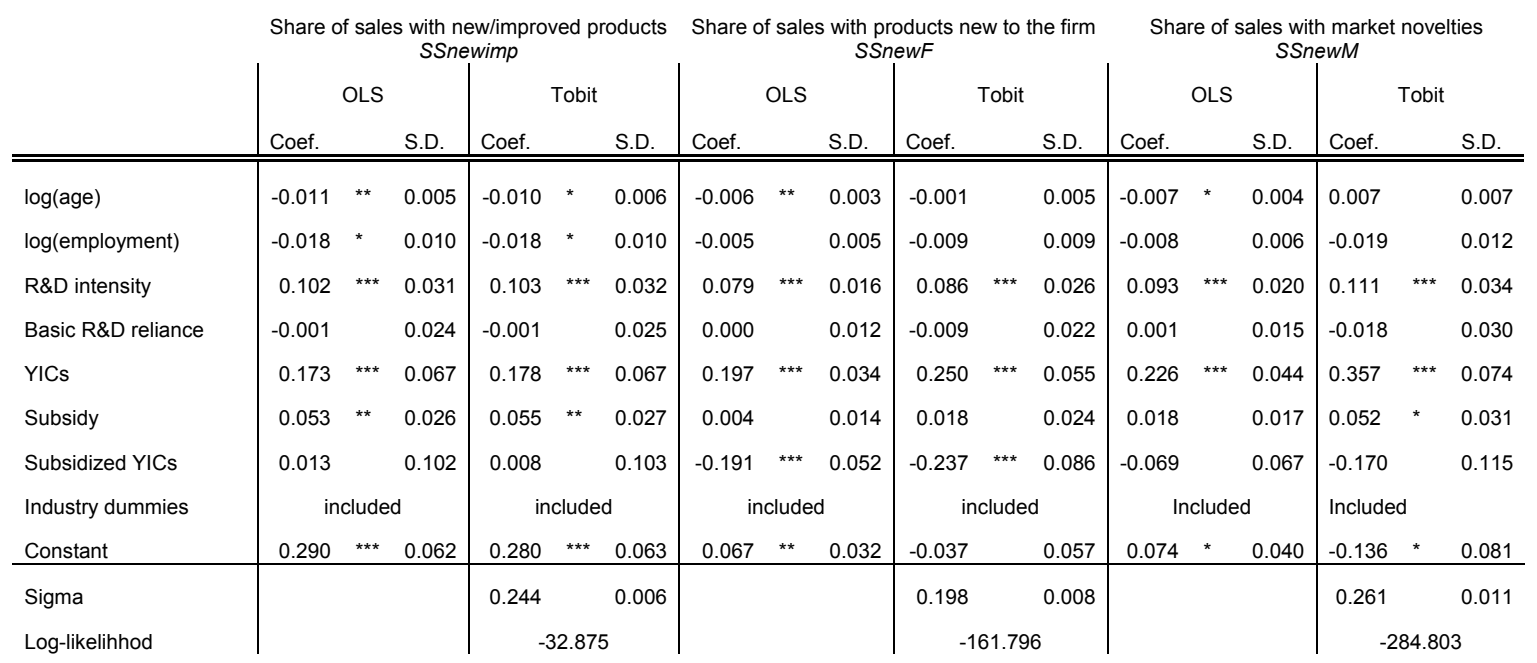


As discussed in Section 3.4, the subsidy dummies are unlikely to be exogenous. Therefore, in order to check the robustness of our results we repeat the previous regressions, instrumenting for the two potentially endogenous variables with the earlier discussed methodology and instruments (share of subsidized firms per industry and per region).

The first stage results are reported in the Appendix. As expected, our excluded instruments are strongly significant. They also reveal that firms performing basic research are more likely to receive subsidies. In addition, firm size and R\&D intensity seems to be important factors that determine the likelihood of receiving public funds: large firms and R\&D intensive firms are more likely to receive subsidies. Interestingly, although the summary statistics reported a high share of YICs receiving subsidies, once correcting for other firm, industry and region characteristics, YICs are not significantly more likely to be receiving subsidies. This result is consistent with the observation that most programs in Germany are not specifically targeted at YICs.

The second stage IV results for innovative performance are presented in Table 7. The IV coefficients are larger in magnitude, and have larger standard errors, resulting in wider confidence intervals, that contain the coefficients found in the previous regressions. Therefore, we cannot conclude that the coefficients associated to the instrumented variables are statistically different from the non-instrumented ones. Regarding the statistical validity of instruments, the tests reported at the bottom of Table 6 indicate that they pass an F-test of excluded instruments and a test of overidentification, as indicated by the Sargan-Hansen statistic.

The instrumented subsidy dummy remains significantly positive in explaining share of sales with new and improved products (SSnewimp). It gains further significance for products with market novelties $(S S n e w M)$, but remains insignificant for products new to the firm $(S S n e w F)$. The negative subsidized YICs dummy now becomes significant at the $10 \%$ level for sales with new/improved products (SSnewimp), and even at the 5\% level for sales with market novelties (SSnewM). This would suggest that subsidized YICs do worse than non-subsidized YICs in terms of new/improved 
products and even more so for products with market novelties. Another way of reading this result is that while in general receiving subsidies improves the innovative performance of innovators, this does not hold for YICs, particularly for improving their innovative performance with respect to products new to the market. Receiving subsidies even reduces the innovative performance of YICs. All this suggests that the system of allocating subsidies in place at the time of the sample, did not succeed in dealing effectively with the specific nature and problems of YICs, associating them with higher innovative performance, particularly their more drastic innovative performance. Since the results suggest on the contrary a significantly negative effect, a hands-off policy vis-à-vis YICs would have given even better results. ${ }^{16}$ It remains to be seen whether a subsidy policy that would be more targeted towards YICs, taking into account their specifics, would have the capacity to generate more positive results.

Table 7: Estimation results for YICs, subsidies and innovative performance (2) IV results

\begin{tabular}{|c|c|c|c|c|c|c|c|c|c|c|c|c|c|c|c|c|c|}
\hline & \multicolumn{6}{|c|}{$\begin{array}{l}\text { Share of sales with new/improved products } \\
\text { SSnewimp }\end{array}$} & \multicolumn{5}{|c|}{$\begin{array}{l}\text { Share of sales with products new to the firm } \\
\text { SSnewF }\end{array}$} & \multicolumn{6}{|c|}{$\begin{array}{c}\text { Share of sales with market novelties } \\
\text { SSnewM }\end{array}$} \\
\hline & \multicolumn{3}{|c|}{ IV } & \multicolumn{3}{|c|}{ IV Tobit } & \multicolumn{3}{|c|}{ IV } & \multicolumn{2}{|c|}{ IV Tobit } & \multicolumn{3}{|c|}{ IV } & \multicolumn{3}{|c|}{ IV Tobit } \\
\hline $\log ($ age $)$ & -0.017 & & 0.011 & -0.017 & & 0.011 & -0.006 & & 0.005 & -0.009 & 0.009 & -0.007 & & 0.008 & -0.016 & & 0.013 \\
\hline log(employment) & -0.017 & $* *$ & 0.007 & -0.016 & ** & 0.007 & -0.006 & * & 0.003 & -0.001 & 0.006 & -0.012 & ** & 0.005 & -0.002 & & 0.009 \\
\hline Basic R\&D reliance & -0.032 & & 0.037 & -0.031 & & 0.038 & 0.000 & & 0.017 & -0.010 & 0.031 & -0.019 & & 0.026 & -0.055 & & 0.045 \\
\hline YICs & 0.571 & ** & 0.244 & 0.573 & ** & 0.248 & 0.174 & & 0.120 & 0.194 & 0.197 & 0.669 & 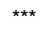 & 0.178 & 0.877 & $\star \star \star *$ & 0.287 \\
\hline Subsidized & 0.279 & $* *$ & 0.129 & 0.273 & ** & 0.132 & -0.001 & & 0.060 & 0.014 & 0.108 & 0.193 & ** & 0.097 & 0.333 & $* *$ & 0.162 \\
\hline Subsidized YICs & -1.170 & * & 0.626 & -1.162 & * & 0.637 & -0.125 & & 0.321 & -0.078 & 0.526 & -1.342 & $\star \star \star *$ & 0.458 & -1.713 & $* *$ & 0.744 \\
\hline
\end{tabular}

\subsubsection{Sensitivity of subsidy effects with respect to the YIC definition}

We check the sensitivity of our subsidy results using alternative scenarios for defining the target population of Young Innovative Companies. Table 8 includes the coefficients on YICs, Subsized and Subsized YICs for the IV Tobit specifications for the various alternative YIC scenarios. Only the results on the SSnewimp and SSnewM innovation performance measures are reported, as the concerned coefficients remain insignificant in the $S S n e w F$ regressions, also in the alternative scenarios.

\footnotetext{
${ }^{16}$ When including on top of the YICs dummy, 3 separate dummies for young age, small size and high RDI, almost the same results are obtained for the YICs, Subsized and Subsized YICs in the three specifications.
} 
Table 8: Estimation results for YICs, subsidies and subsidzed YICs in innovative performance for alternative YIC scenarios

\begin{tabular}{|c|c|c|c|c|c|c|c|c|c|}
\hline \multicolumn{10}{|c|}{ IV Tobit Results } \\
\hline & \multicolumn{3}{|c|}{$\begin{array}{c}\text { Alternative YIC } \\
\text { scenarios }\end{array}$} & \multicolumn{3}{|c|}{ SSnewimp } & \multicolumn{3}{|c|}{ SSnewM } \\
\hline & Age & Size & RDI & YICs & Subsidized & $\begin{array}{c}\text { Subsidized } \\
\text { YICs } \\
\end{array}$ & YICs & Subsidized & $\begin{array}{c}\text { Subsidized } \\
\text { YICs } \\
\end{array}$ \\
\hline 1 & $<6$ & $<250$ & $>15 \%$ & $0.573 * *$ & $0.273 * *$ & $-1.162 *$ & $0.877 * * *$ & $0.333 * *$ & $-1.713 * *$ \\
\hline 2 & $<15$ & $<250$ & $>15 \%$ & $0.356 * * *$ & $0.228^{*}$ & -0.407 & $0.597 * *$ & $0.290^{*}$ & -0.943 \\
\hline 3 & All & $<250$ & $>15 \%$ & $0.186^{* * *}$ & 0.196 & 0.126 & $0.202 * * *$ & 0.118 & -0.423 \\
\hline 4 & $<6$ & $<250$ & $>8 \%$ & 0.221 & $0.330 * *$ & -0.260 & $0.380 * *$ & $0.373 * *$ & -0.678 \\
\hline 5 & $<6$ & $<250$ & All & 0.058 & $0.339 * *$ & -0.168 & 0.017 & $0.346 * *$ & 0.101 \\
\hline 6 & $<15$ & $<500$ & $>8 \%$ & $0.301 * * *$ & $0.331 * *$ & $-0.485 * *$ & $0.323 * * *$ & $0.375 * *$ & $-0.484 * *$ \\
\hline
\end{tabular}

When softening the criteria for YICs across scenarios, the superior innovative performance of YICs looses importance. This holds again especially for the new-tothe-market innovative performance. In some cases, it even looses significance. The differential subsized YICs effect remains negative in most cases, but looses at least size and almost always even significance. Hence, expanding the criteria for the target population, makes YICs less adversely affected by subsidies, but at the same time also less exceptional in their innovative performance. Again, the NTBF category leaves no significant results.

\section{Conclusion}

Recent policy initiatives, such as the creation of the YICs status at the European level, aim at improving the financial environment for European entrepreneurial activity and more specifically to support newly-founded innovative firms in order to increase their global competitiveness and spur innovation. But are young innovative companies indeed the most promising actors for innovation? And can policy intervention make a difference for these companies?

Our econometric results, using German CIS data, confirm the presumption that young, small, innovation-intensive firms, a very small but distinct segment in the group of innovative companies, achieve significantly higher innovative sales than do other innovation-active firms. This result is particularly strong for more "radical" type of innovations, and comes on top of controls for non-linear age, size and R\&D intensity effects. We also find that access to finance is the most important factor that hampers 
YICs' innovation activities, significantly more than other innovating firms. In our German sample, most public policies toward innovations are general and have no specific focus on YICs and their distinctive characteristics. When evaluating the effectiveness of these general R\&D innovation subsidy schemes, we find that while on average $R \& D$ subsidies increase the innovative performances of innovating firms in our sample, this result does not hold for YICs. We also find that the results are robust to small and unidimensional changes in the criteria for identifying YICs. With multidimensional and more substantial changes in the criteria, particularly with respect to $\mathrm{R} \& \mathrm{D}$ intensity, the larger target group of companies becomes less exceptional in their innovative performance, particularly on radical innovativeness, but at the same time also less likely to be adversely affected by subsidies.

A full welfare analysis of a policy targeted at YIC is clearly beyond the scope of this paper, requiring a performance analysis extending beyond innovative performance and including indirect effects on other market participants. A few partial policy insights can nevertheless be generated. The extremely small number of relevant target companies, puts in perspective the prospects of motivating policy attention towards YICs in their capacity of job creation as a response to high unemployment rates. However, as shown in our analysis, their social value and therefore policy interest, rests on their potential to introduce substantially new innovations, on which other innovators can further build. Therefore, if policy makers want to help overcome the barriers that YICs face, in particular the finance barrier, they should take into account the specific nature of YICs to be more effectively targeting this group.

Our analysis of the innovative success of YICs opens several opportunities for future work. First, this paper has focused on public subsidies as a potential answer to financial constraints. Kortum and Lerner (2000) show that Venture Capital (VC) accounts for a large share of industrial innovations in the U.S. Therefore, future research should focus on whether VC affects YICs' innovative performances and whether there is likely to be synergies between VC funding and public subsidies. Second, the commercialization strategies of young innovative firms are a crucial determinant of their success. Therefore, in future work, we will attempt to analyze these strategies that could take the form of either cooperation with established companies (Gans, Hsu and Stern, 2002) or competition on the product market. 
Finally, the innovative success of YICs, in competition or cooperation with established companies, might be linked to their appropriation strategies, which is why future research should also include the strength of the appropriation regime.

\section{References}

Almus, M. and Czarnitzki, D. (2001), "The Effects of Public R\&D Subsidies on Firms' Innovation Activities: The Case of Eastern Germany", Journal of Business and Economic Statistics, 21 (2), 226.236.

Acs, Z. and Audretsch, D. (1987), "Innovation, Market Structure and Firm Size", Review of Economics and Statistics, 71, 567-574.

Aerts, K. (2008), "Who Writes the Pay Slip? Do R\&D Subsidies Merely Increase Researchers Wages?", Unpublished Manuscript, K.U. Leuven.

Angrist, J. (2001), "Estimation of Limited-Dependent Variable Models with Binary Endogenous Regressors: Simple Strategies for Empirical Practice", Journal of Business and Economic Statistics.

Anton, J. and Yao, D., "Expropriation and Inventions: Appropriable Rents in the Absence of Property Rights." American Economic Review, 84(1), 190-209.

Bartelsman, E., Haltiwanger, J. and Scarpetta, S. (2004): "Microeconomic Evidence of Creative Destruction in Industrial and Developing Countries," IZA Discussion Paper Series No. 1374

Baumol (2002), The Free-Market Innovation Machine, Princeton University Press.

BEPA (2008), Innovation and Growth in the EU: the role of SME policy, European Commission 
Canepa, A. and Stonemann, P. (2008), "Financial constraints to innovation in the UK: evidence from CIS2 and CIS3", Oxford Economic Papers, forthcoming.

Cassiman, B. and Veugelers, R. (2006), "In Search of Complementarity in the Innovation Strategy: Internal R\&D and External Knowledge Acquisition", Management Science, 52 (1), 68-82.

Christensen, C. (1997), The Innovator's Dilemma: when new technologies cause great firms to fail, Harvard Business School Press, Boston MA

Cohen, W.M., Nelson, R.R., Walsh, J.P., 2000. Protecting their intellectual assets: appropriability conditions and why U.S. manufacturing firms patent (or not). NBER Working Paper 7552.

Cohen, W. M. and Levin, R. C. (1989), "Empirical Studies of Innovation and Market Structure", in Schmalensee \& Willig (Eds), Handbook of Industrial Organisation, North Holland.

Colombo, M., Giannangeli, S. and Grilli, L. (2008), “A longitudinal analysis of public financing and the growth of New Technology-based Firms: do firms' age and applicants' evaluation methods matter?", Unpublished Manuscript.

Czarnitzki, D. and Aerts, K. (2004), "Using innovation survey data to evaluate R\&D policy: The case of Belgium”, ZEW Discussion Paper 04-55, Mannheim.

David, P. A., Hall, B. H., and Toole, A. A. (2000), "Is Public R\&D a Complement or a Substitute for Private R\&D? A Review of the Econometric Evidence", Research Policy, 29, 497-529.

Gans, J. and Stern, S. (2000), "Incumbency and R\&D Incentives: Licensing the Gale of Creative Destruction", Journal of Economics and Management Strategy.

Gans, J. ans Stern, S. (2003), "When Does Funding Research by Smaller Firms Bear Fruit?: Evidence from the SBIR", Economics of Innovation and New Technology.

Gans, J., Hsu, D. and Stern, S. (2002) "When Does Start-up Innovation Spur the Gale of Creative Destruction?", RAND Journal of Economics.

Gilbert, R. and Newbery, D. M. G. (1982), "Preemptive Patenting and the Persistence of Monopoly" American Economic Review, 72(3), 514-526.

Gonzalez, X., Jaumandreu, J. and Pazo, C. (2005), "Barriers to innovation and subsidy effectiveness", Rand Journal of Economics, 36 (4), 930-950.

Hall, B.H., (2005) "The Financing of Innovation," in Shane, S. (ed.), Blackwell Handbook of Technology and Innovation Management, Oxford: Blackwell Publishers, Ltd., 2005. 
Heckman, J. H., Ichimura, H., Smith, J., and Todd, P. (1998), "Characterizing Selection Bias Using Experimental Data”, Econometrica, 66, 1017-1098.

Henderson, R. "Underinvestment and Incompetence as Responses to Radical Innovation: Evidence from the Photolithographic Industry", Rand Journal of Economics, 24(2).

Henderson, R. and Clark, K. (1990) "Architectural Innovation: The Reconfiguration of Existing Product Technologies and the Failure of Established Firms", Administrative Science Quarterly, 35, 9-30.

Holzl, W. (2008), Is R\&D behavior of fast growing SMEs different?, WIFO Working Paper 327.

Hussinger, K. (2008), "R\&D and Subsidies at the Firm Level: An Application of Parametric and Semi-Parametric Two-Step Selection Models", Journal of Applied Econometrics, forthcoming.

Jaffe, A. (2002), "Building Program Evaluation into the Design of Public ResearchSupport Programs" Oxford Review of Economic Policy, 18 (1), 22-34.

Kamien \& Schwartz (1982), "Market Structure and Innovation", Cambridge University Press

Klepper, S. (1996), "Entry, Exit, Growth, and Innovation Over the Product Life Cycle" American Economic Review.

Klette, T. J., Møen, J. and Griliches, Z. (2000), "Do Subsidies to Commercial R\&D Reduce Market Failures? Microeconometric Evaluation Studies", Research Policy 29, 471-495.

Kortum, S. and Lerner, J. (2000), “Assessing the Contribution of Venture Capital to Innovation", RAND Journal of Economics, 31(4), 674-692.

Lach, S. (2002), "Do R\&D Subsidies Stimulate or Displace Private R\&D? Evidence from Israel", Journal of Industrial Economics, 50(4), 369-390.

Licht, G. and Nerlinger, E. (1998), "New Technology-Based Firms in Germany: a Survey of the Recent Evidence", Research Policy, 26, 1005-1022.

Lichtenberg, F. (1988), "The Private R\&D Investment Response to Federal Design and Technical Competitions", American Economic Review, 36, 97-104.

Little, A.D. (1977), "New Technology-Based Firms in the United Kingdom and the Federal Republic of Germany" A Report prepared for the Anglo-German Foundation for the Study of Industrial Society, London.

Mohnen, P., Palm, F., van der Loeff, S.S. and Tiwari, A. (2008), "Financial Constraints and Other Obstacles: Are they a Threat to Innovation Activity?", UNU-MERIT Working Paper 2008-006. 
Reinganum, J. F. (1983), "Uncertain Innovation and the Persistance of Monopoly", American Economic Review, 73, 741-748.

Rothaermel, F. (2008), University entrepreneurship: a taxonomy of the literature, Industrial and Corporate Change, forthcoming

Savignac, F. (2008), "The Impact of Financial Constraints on Innovation: What Can Be Learned From a Direct Measure?" Economics of Innovation and New Technology, forthcoming.

Storey, D.J., Tether, B.S. (1998), "New technology-based firms in the European Union: an introduction", Research Policy, 26, 933-946.

Véron, N. and Philippon, T. (2008) "Financing Europe's Fast Movers", Bruegel Policy Brief

Takalo, T., Tanayama, T. and Toivanen, O. (2008), "Evaluating innovation policy: a structural treatment effect model of R\&D subsidies," Research Discussion Papers 7/2008, Bank of Finland.

Teece, D. (1986), "Profiting from Technological Innovation”, Research Policy, 15(6), 285-305

Tiwari, A., Mohnen, P., Palm, F. and van der Loeff, S.S. (2007), "Financial constraint and R\&D investment: Evidence from CIS", in: A. Kleinknecht, R. Ott, C. van Beers \& R. Verburg (Eds.), Determinants of Innovative Behaviour: A Firm's Internal Practices and Its External Environment, Palgrave Publishers, London

Utterback, J. (1996), Mastering the Dynamics of Innovation, Harvard Business School Press.

Wallsten, S. J. (2000), "The Effects of Government-Industry R\&D Programs on Private R\&D: the Case of the Small Business Innovation Research Program", RAND Journal of Economics 31(1), 82-100.

Wooldridge, J. M., (2002), "Econometric Analysis of Cross Section and Panel Data", MIT Press Cambridge. 


\section{Appendix 1: List of variables}

\begin{tabular}{|c|c|}
\hline Variable & Definition \\
\hline Share of sales with new products & $\begin{array}{l}\text { Percentage of total sales derived from } \\
\text { new or substantially improved products } \\
\text { introduced between } 2002 \text { and } 2004\end{array}$ \\
\hline $\begin{array}{l}\text { Share of sales with products new to the } \\
\text { firm }\end{array}$ & $\begin{array}{l}\text { Percentage of total sales derived from } \\
\text { new products with no predecessor within } \\
\text { the firm, introduced between } 2002 \text { and } \\
2004\end{array}$ \\
\hline $\begin{array}{l}\text { Share of sales with products new to the } \\
\text { market }\end{array}$ & $\begin{array}{l}\text { Percentage of total sales derived from } \\
\text { new products with no predecessor on the } \\
\text { market, introduced between } 2002 \text { and } \\
2004\end{array}$ \\
\hline Size & Number of employees \\
\hline Age & Number of years since foundation \\
\hline R\&D intensity & $\begin{array}{l}\text { Amount of R\&D expenditures relative to } \\
\text { sales }\end{array}$ \\
\hline YIC & $\begin{array}{l}=1 \text { if age }<=6, \text { size }<=250 \text { and } R \& D \\
\text { intensity }>=15 \%\end{array}$ \\
\hline Basic R\&D reliance & $\begin{array}{l}\text { Measure of importance for the innovation } \\
\text { process of information from research } \\
\text { institutes and universities relative to the } \\
\text { importance of suppliers and customers as } \\
\text { an information source. }\end{array}$ \\
\hline Subsidized & $\begin{array}{l}=1 \text { if the firm received an R\&D subsidy } \\
\text { from the German Federal Governement, } \\
\text { from the regional authorities, from the } \\
\text { European Union or from another source, } \\
\text { between } 2002 \text { and } 2004 .\end{array}$ \\
\hline Subsidized YIC & $=$ Subsidized x YIC \\
\hline Share of subsidized firms per region & $\begin{array}{l}\text { Number of firms that received a subsidy } \\
\text { relative to the total number of firms per } \\
\text { region (Bundesland) }\end{array}$ \\
\hline Share of subsidized firms per industry & $\begin{array}{l}\text { Number of firms that received a subsidy } \\
\text { relative to the total number of firms per } \\
\text { industry (defined at the NACE 2-digit } \\
\text { level) }\end{array}$ \\
\hline
\end{tabular}




\section{Appendix 2: Econometric evidence on YICs and financial constraints}

The descriptive statistics showed that YICs seem to be more hampered by the lack of available finances. In order to further investigate this finding, we estimate an order probit model relating the scores of (perceived) external and internal financing constraints as barriers to innovation (on a scale from zero to three), to the YICs and a set of control variables.

Our estimations, using ordered probit analysis (in a similar way to Canepa and Stoneman, 2008), confirm that YICs are more likely to suffer from financial constraints. In addition and as expected, the estimations show that big firms are less likely to be financially constraint, whereas firms that do more basic R\&D are more likely to consider internal and external lack of finances as an obstacle to innovation. The thresholds parameters correspond to the estimated cut-off points for the probability of the four possible outcomes.

\begin{tabular}{|c|c|c|c|c|}
\hline \multirow[b]{2}{*}{ Variables } & \multicolumn{2}{|c|}{$\begin{array}{l}\text { Internal financial } \\
\text { constraints }\end{array}$} & \multicolumn{2}{|c|}{$\begin{array}{l}\text { External financial } \\
\text { constraints }\end{array}$} \\
\hline & Coef. & S.D. & Coef. & S.D. \\
\hline $\log ($ age $)$ & -0.009 & 0.034 & -0.017 & 0.035 \\
\hline log(employment) & $-0.106 * * *$ & 0.019 & $-0.150 \quad * * *$ & 0.019 \\
\hline$R \& D$ intensity & 0.246 & 0.203 & 0.292 & 0.207 \\
\hline YICs & $0.780 * * *$ & 0.206 & $0.516 * * *$ & 0.200 \\
\hline Basic $R \& D$ reliance & $0.175 * *$ & 0.077 & $0.191 * *$ & 0.078 \\
\hline Industry dummies & \multicolumn{2}{|c|}{ Included } & \multicolumn{2}{|c|}{ Included } \\
\hline Threshold 1 & -0.896 & 0.238 & -1.052 & 0.242 \\
\hline Threshold 2 & 0.010 & 0.237 & -0.282 & 0.241 \\
\hline Threshold 3 & 0.745 & 0.238 & 0.345 & 0.241 \\
\hline Log-likelihood & \multicolumn{2}{|c|}{-1652.010} & \multicolumn{2}{|c|}{-1620.057} \\
\hline Number of observations & \multicolumn{2}{|c|}{1250} & \multicolumn{2}{|c|}{1246} \\
\hline
\end{tabular}

For all other barriers, the YICs variable is not significantly different from zero. These estimates are not reported for brevity. 


\section{Appendix 3: First stage regressions}

The table reports the first stage results for subsidies on three samples, since the number of available observations is somewhat different for the three dependent variables.

\begin{tabular}{|c|c|c|c|c|c|c|c|c|c|c|c|c|c|c|c|c|c|c|}
\hline & \multicolumn{6}{|c|}{ Share of sales with products } & \multicolumn{6}{|c|}{ Share of sales with products new to the firm } & \multicolumn{6}{|c|}{ Share of sales with market novelties } \\
\hline & \multicolumn{3}{|c|}{ Subsidy } & \multicolumn{3}{|c|}{ Subsidized YICs } & \multicolumn{3}{|c|}{ Subsidy } & \multicolumn{3}{|c|}{ Subsidized YICs } & \multicolumn{3}{|c|}{ Subsidy } & \multicolumn{3}{|c|}{ Subsidized YICs } \\
\hline & Coef. & & S.D. & Coef. & & S.D. & Coef. & & S.D. & Coef. & & S.D. & Coef. & & S.D. & Coef. & & S.D. \\
\hline $\log ($ age $)$ & -0.005 & & 0.014 & 0.000 & & 0.004 & -0.005 & & 0.014 & 0.000 & & 0.004 & -0.004 & & 0.014 & 0.000 & & 0.004 \\
\hline log(employment) & 0.031 & $* \star *$ & 0.008 & 0.000 & & 0.002 & 0.030 & *** & 0.007 & 0.000 & & 0.002 & 0.033 & $* \star *$ & 0.008 & 0.000 & & 0.002 \\
\hline R\&D intensity & 0.091 & ** & 0.047 & 0.072 & *** & 0.012 & 0.086 & * & 0.046 & 0.067 & *** & 0.012 & 0.091 & ** & 0.047 & 0.072 & $* \star \star$ & 0.012 \\
\hline Basic $R \& D$ reliance & 0.176 & $\star * *$ & 0.034 & 0.011 & & 0.009 & 0.179 & $* * *$ & 0.032 & 0.011 & & 0.008 & 0.171 & $\star * *$ & 0.032 & 0.010 & & 0.008 \\
\hline YICs & -0.069 & & 0.650 & -0.400 & ** & 0.169 & -0.024 & & 0.645 & -0.348 & ** & 0.170 & -0.080 & & 0.650 & -0.400 & ** & 0.168 \\
\hline Share of subsidized firms $p$. region & 1.996 & $* \star *$ & 0.434 & -0.019 & & 0.113 & 2.196 & *** & 0.448 & -0.004 & & 0.118 & 2.061 & $\star \star \star *$ & 0.442 & -0.023 & & 0.115 \\
\hline Share of subsidized firms $p$. industry & 0.954 & 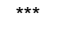 & 0.249 & -0.076 & & 0.065 & 0.888 & *** & 0.246 & -0.083 & & 0.065 & 0.851 & $\star \star \star *$ & 0.249 & -0.074 & & 0.065 \\
\hline Share of subsidized firms $p$. region ${ }^{\star} Y I C s$ & 5.858 & & 8.059 & 9.753 & *** & 2.091 & 4.798 & & 7.956 & 8.599 & *** & 2.101 & 5.933 & & 8.053 & 9.762 & $* \star \star$ & 2.086 \\
\hline Share of subsidized firms $p$. industry ${ }^{*} Y I C s$ & -1.296 & * & 0.665 & 0.129 & & 0.173 & -1.160 & * & 0.649 & 0.284 & * & 0.171 & -1.244 & * & 0.665 & 0.129 & & 0.172 \\
\hline Industry dummies & & cludec & & & cludec & & & cluded & & & cluded & & & cluded & & & clude & \\
\hline Constant & -0.343 & 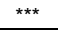 & 0.096 & -0.005 & & 0.025 & -0.356 & *** & 0.096 & -0.006 & & 0.025 & -0.347 & $* \star \star$ & 0.097 & -0.004 & & 0.025 \\
\hline $\begin{array}{l}\text { Number of observations available } \\
\text { Diagnostic test and statistics } \\
\text { (based on linear regression model) }\end{array}$ & \multicolumn{6}{|c|}{761} & \multicolumn{6}{|c|}{767} & \multicolumn{6}{|c|}{765} \\
\hline $\mathrm{F}$ test of excluded instruments & \multirow{2}{*}{\multicolumn{2}{|c|}{$9.09^{* * *}$}} & \multirow{2}{*}{\multicolumn{4}{|c|}{$5.72^{\star \star \star}$}} & \multirow{2}{*}{\multicolumn{2}{|c|}{$9.41^{* \star *}$}} & \multirow{2}{*}{\multicolumn{4}{|c|}{$4.65^{\star \star \star}$}} & \multirow{2}{*}{\multicolumn{2}{|c|}{$8.58^{* * *}$}} & & \multirow{2}{*}{\multicolumn{3}{|c|}{$5.73^{\star \star \star}$}} \\
\hline Sargan-Hansen Statistic & & & & & & & & & & & & & & & & & & \\
\hline
\end{tabular}

